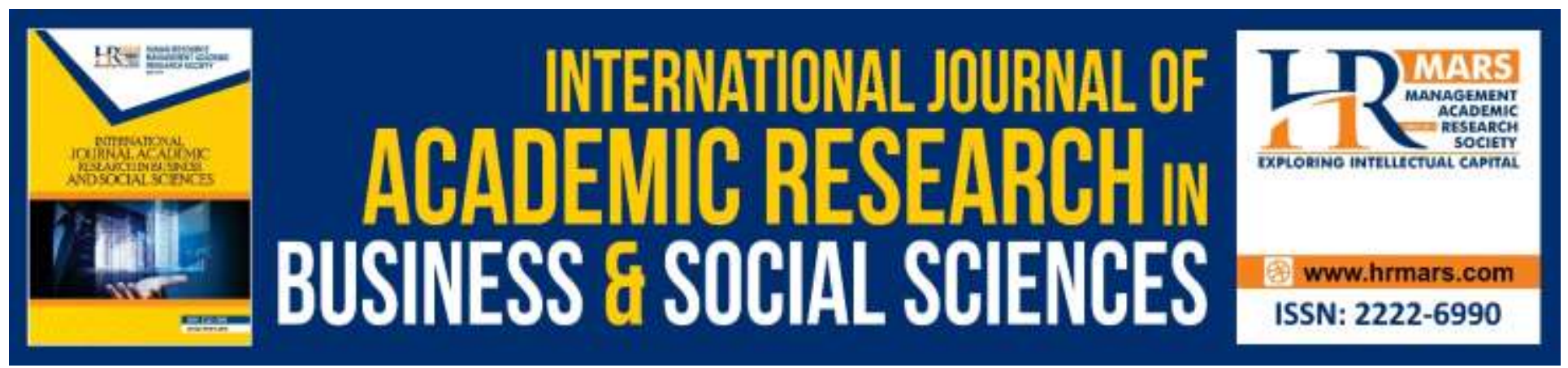

\title{
TVETagogy: Teaching and Facilitating Framework (PDPC) for Technical and Vocational Education and Training (TVET)
}

Ridzwan Che Rus, Mohd Azlan Mohamad Husain, Zaliza Hanapi and Abu Bakar Mamat

To Link this Article: http://dx.doi.org/10.6007/IJARBSS/v10-i3/7082

DOI:10.6007/IJARBSS/v10-i3/7082

Received: 03 February 2020, Revised: 24 February 2020, Accepted: 11 March 2020

Published Online: 30 March 2020

In-Text Citation: (Rus et al., 2020)

To Cite this Article: Rus, R. C., Husain, M. A. M., Hanapi, Z., \& Mamat, A. B. (2020). TVETagogy: Teaching and Facilitating Framework (PdPc) for Technical and Vocational Education and Training (TVET). International Journal of Academic Research in Business and Social Sciences, 10(3), 679-687.

Copyright: (C) 2020 The Author(s)

Published by Human Resource Management Academic Research Society (www.hrmars.com)

This article is published under the Creative Commons Attribution (CC BY 4.0) license. Anyone may reproduce, distribute, translate and create derivative works of this article (for both commercial and non-commercial purposes), subject to full attribution to the original publication and authors. The full terms of this license may be seen at: http://creativecommons.org/licences/by/4.0/legalcode

Vol. 10, No. 3, 2020, Pg. 679 - 687

http://hrmars.com/index.php/pages/detail/IJARBSS

JOURNAL HOMEPAGE

Full Terms \& Conditions of access and use can be found at http://hrmars.com/index.php/pages/detail/publication-ethics 


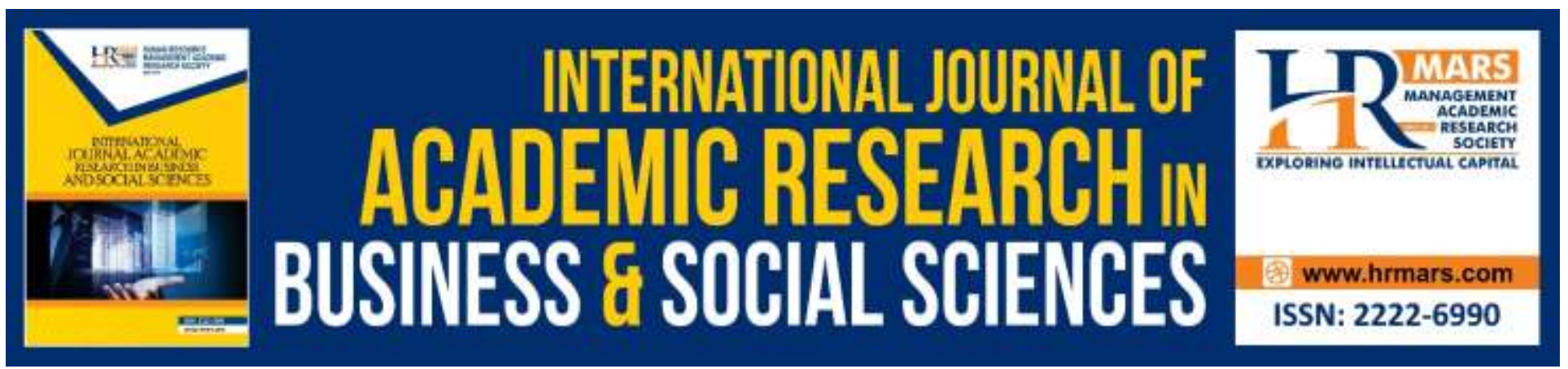

\title{
TVETagogy: Teaching and Facilitating Framework (PDPC) for Technical and Vocational Education and Training (TVET)
}

\author{
Ridzwan Che Rus, Mohd Azlan Mohamad Husain, Zaliza Hanapi \\ and Abu Bakar Mamat
}

Faculty of Technical and Vocational, Universiti Pendidikan Sultan Idris, Perak, Malaysia

\begin{abstract}
The quality of TVET graduates is often an issue raised by employers, particularly the Malaysian Employers Federation (MEF) and the Federation of Malaysian Manufacturers (FMM). One of the important factors in producing quality graduates is the teaching and learning method (PdPc) practiced in TVET training institutions. Therefore, the study was conducted to develop a PdPc framework known as TVETagogy, particularly in the field of TVET in Malaysia. This framework was developed on the basis of Project Oriented Problem Based Learning (POPBL) and Work-Based Learning (WBL) combined with 21st-century teaching elements. A total of 9 experts have been appointed using Delphi's modified method to validate the elements related to TVETagogy. The findings show that technology elements, pedagogy, content, knowledge have been successfully integrated with POPBL and WBL elements to create a framework for TVETagogy. The findings of this study can be used for future teachers, educators in the field of TVET for guidance in designing high quality and effective PdPc TVET to produce high skilled workforce.
\end{abstract}

Keywords: TVETagogy, TVET, Project Oriented Problem Based Learning (POPBL), Work-Based Learning (WBL), Teaching and Facilitating (PDPC)

\section{Introduction}

UNESCO through its 4th UNESCO Sustainable Development Goal 2030, which supports lifelong education raises issues of equality and quality educational opportunities for all peoples of the world. This is in line with the 2015-2025 Malaysian Education Development Plan which emphasizes the 4th surge, namely the quality of TVET graduates (PPPM, 2015). Previous studies (Department of Labour, 2012; Ministry of Human Resources, 2011; UPM, 2012; Ridzwan et al., 2015) have found that graduates of Public Skills Training Institution and public universities in Malaysia have basic skills. However, they are less competent in the technical skills required by the industry, and they do not have good soft skills, including professional work ethic, communication skills, teamwork, decisionmaking and leadership. 
INTERNATIONAL JOURNAL OF ACADEMIC RESEARCH IN BUSINESS AND SOCIAL SCIENCES

Vol. 10, No. 3, March, 2020, E-ISSN: 2222-6990 @ 2020 HRMARS

One of the reasons why the Malaysian education system is lagging behind is the outdated teaching method that needs to be changed (Mahathir, 2018) and not supported by the humanitarian process (Malik, 2018). Therefore, appropriate teaching methods need to be consistent with the changes and challenges of the industrial revolution 4.0 and education 4.0 in order to produce knowledgeable and holistic human capital. In the context of revised accreditation criteria and calls from industry about what they need from engineering graduates, it would appear that this claim is unlikely to be met by traditional engineering curriculum and "chalk and talk" pedagogy (Julie \& David, 2003, and Jusoh, 2016).

\section{Work-Based Learning and Project Oriented Problem Based Learning}

Alias (2019) notes that through TVET teachers' understanding of pedagogical knowledge and the 21st century curriculum can help to enhance technology and innovation skills in TVET education itself. Therefore, this study will combine Work-Based Learning and Project Oriented Problem Based Learning together with the TPACK model (Koehler and Mishra, 2009).

\section{Work-Based Learning}

Work-based learning is often described as an informal learning environment and informal learning (Spottl, 2007). Therefore, public perception has always shown that learning through work is informal. This is not true (Billet, 2002). A narrow understanding of the learning process at work has led employers to underestimate the importance of learning. Similar to vocational training institutions, workplaces also emphasize work practices, structures, and activities that are based on goals that are essential to organizational sustainability, as well as interaction and performance-based judgment of performance (Berge, 2008; Boud and Middleton, 2003, Conor and Richard, 2013; Griffith and Guile, 2003; Nor Aishah et al., 2007; Ruhizan et al., 2014; Shamuni and Ruhizan, 2010). Implementation of work-based learning should have a clear structure for the relationship between training institutions and the workplace.

Work-based training institutions and learning programs cannot be separated because they need each other (JPP, 2009; Mohamad and Norhayati, 2011; Nor Aishah et al., 2007; Shamuni and Ruhizan, 2010). The skills required by the industry are the benchmarks for the success of the training system (Spootl, 2000) as the main goal of the skills training center to meet the demands of the industry. Therefore, knowledge of work-based learning is important because the success of workbased learning depends on the effectiveness and strength of both parties (JPP, 2009; Mohamad and Norhayati, 2011; Pot, 2011; Rashidi, 2013; Ruhizan et al., 2007; Shamuni and Ruhizan, 2010). Good collaboration between both parties will contribute to the development of students according to the quality required by the industry.

\section{Project Oriented Problem Based Learning}

The POPBL approach is implemented as a project-based project, where students are given real-world problems for specialized case study applications and current in-trend software that is complex for beginner students (Noraini and Shahliza, 2013). The results also show that students are highly motivated and satisfied with the implementation of POPBL to improve their skills (communication 
INTERNATIONAL JOURNAL OF ACADEMIC RESEARCH IN BUSINESS AND SOCIAL SCIENCES Vol. 10, No. 3, March, 2020, E-ISSN: 2222-6990 @ 2020 HRMARS

between team and planning) and their technical skills (analyzing real-world problems, designing structured solutions and developing products).

The use of project-based learning as an essential component of engineering programs should be as widely stated as possible, as it is clear that any improvement to engineering-mastered college programs will be welcomed by students, industry and accreditors (Julie and David, 2003). A good curriculum and training system supports the production of trainees through high quality training systems.

\section{Research Framework}

Figure 1 show this research framework. This framework based on the ADDIE Development Model.
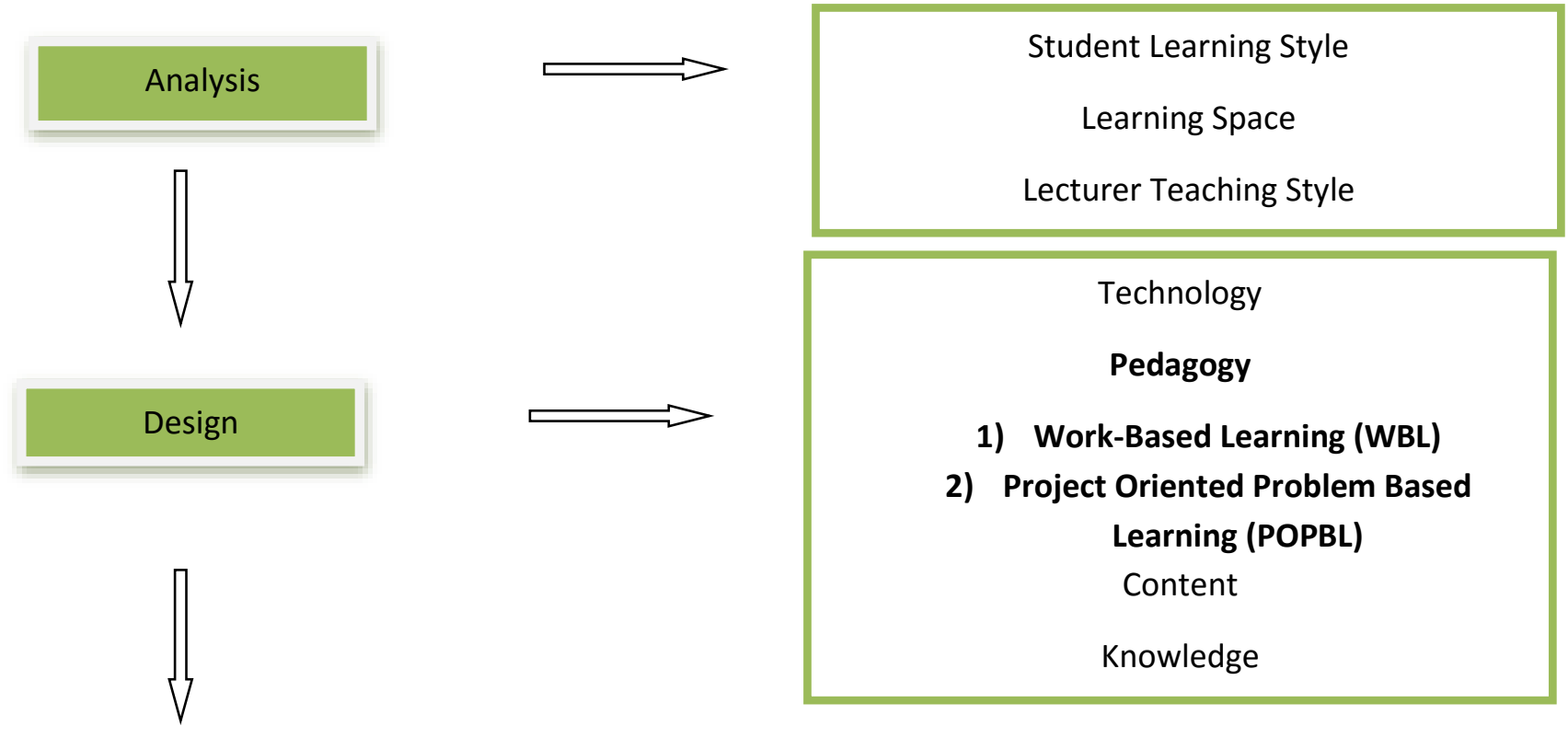

\section{Technology \\ Pedagogy}

1) Work-Based Learning (WBL)

2) Project Oriented Problem Based

Learning (POPBL)

Content

Knowledge

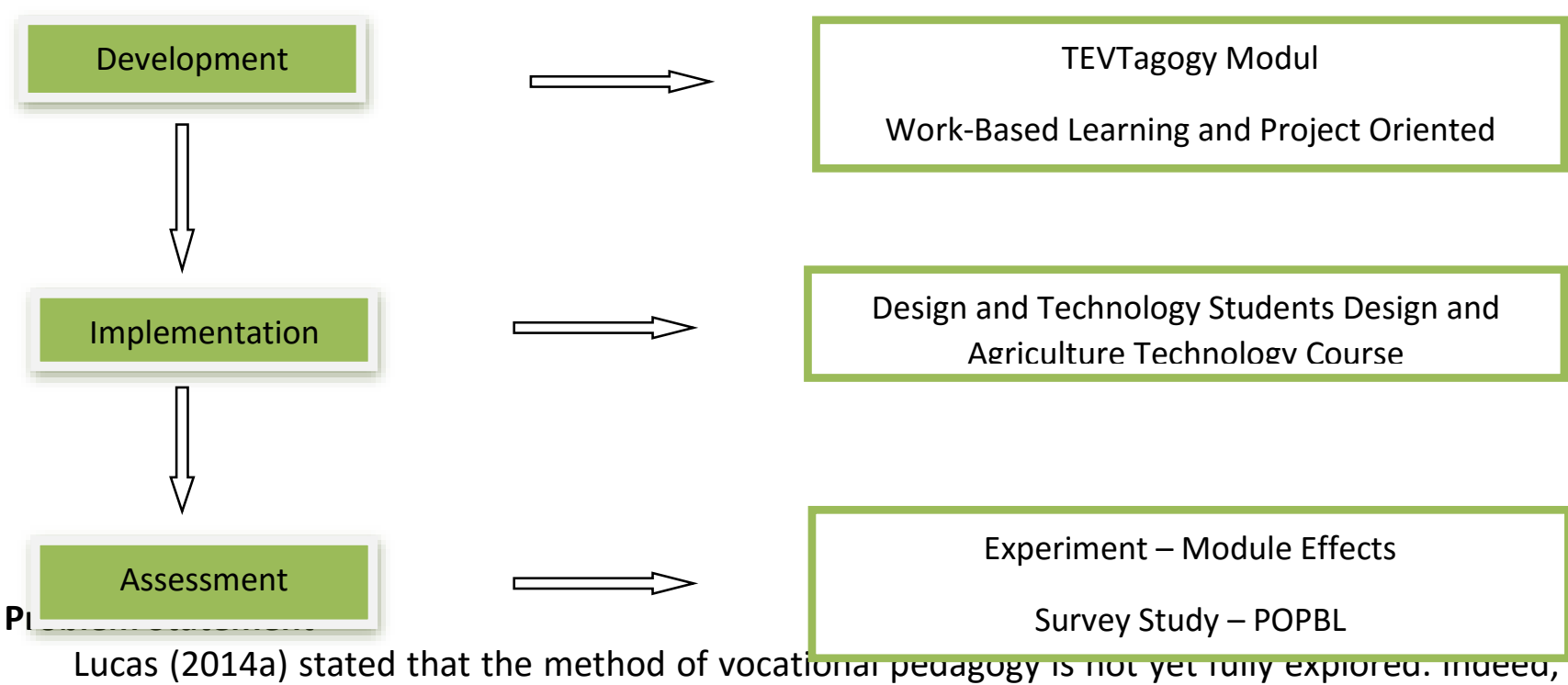


Vocational Education and Training (VET) is often associated with academic education. In some countries, pedagogy or better known as androgyny in Knowles (1984) has been widely debated. There was a lively discussion about the best way to teach vocational education.

Previous studies (Department of Labour, 2012; Ministry of Human Resources, 2011; Malaysia, 2010; Center for Advanced Training and Teaching, 2007; Ramlee and Abu, 2004; UPM, 2012, Ridzwan, 2015, EDGE UPSI, 2017) have found that graduates of Public Skills Training Institution and public universities in Malaysia have basic skills. However, they are less competent in the technical skills required by the industry, and they do not have good soft skills, including professional work ethic, communication skills, teamwork, decision-making and leadership.

Therefore, this issue needs to be explored in training institutions, in particular UPSI which plays a role in producing knowledgeable and skilled future teachers, lecturers and workers trained by existing educators. One of the reasons why the Malaysian education system is lagging behind is the outdated teaching method that needs to be changed (Mahathir, 2018) and not supported by the humanitarian process (Malik, 2018).

\section{Objective of the Study}

To develop the appropriate Teaching Model for Technical and Vocational Education and Training Teachers (TVETaGogy) via Project Oriented Problem Based Learning and Work Based Learning.

\section{Research Question}

What is the appropriate Teaching Model for Technical and Vocational Education and Training Teachers (TVETaGogy) via Project Oriented Problem Based Learning and Work Based Learning?

\section{Methodology}

This research uses Delphi survey techniques and frameworks adapted from Creswell (2003). The study was conducted by two main stages, namely:

\section{The First Stage}

At this stage, researchers need to develop structured questions for the interview instrument for the Delphi technique. The tuition instruments built are based on previous research, related to the development of the TVETagogy framework. Further, the improvement/standardization of the questionnaire instrument was done by two experts in education.

\section{The Second Stage}

Asnul (2012) stated that the Delphi technique is one of the research methods, which can obtain genuine agreement/consensus from the expert panel as each expert does not know each other and the expert panel consensus is reached without prejudice/bias, influence or pressure from any party. Thus, the second stage of this modified Delphi study goes through several stages for expert verification to reach consensus on the TVETagogy framework.

\section{Sampling}

For this study, the researchers selected 9 participants/respondents as Delphi's expert panel. Linstone and Turoff (1975) have suggested five to ten expert panels as suitable/appropriate number for 
INTERNATIONAL JOURNAL OF ACADEMIC RESEARCH IN BUSINESS AND SOCIAL SCIENCES

Vol. 10, No. 3, March, 2020, E-ISSN: 2222-6990 C 2020 HRMARS

research using the Delphi technique. The panel of Delphi experts involved in the study consisted of three lecturers from Sultan Idris Education University (UPSI), two experts from Tun Hussein Onn University of Malaysia (UTHM) and 4 experts from the Vocational College under the Ministry of Education Malaysia (MOE).

\section{Data Analysis}

In each round, the experts examined the contents of the questionnaire and added new items if necessary/required. The process of completion/coordination of the questionnaire was carried out in each round, based on the results of the research and experts opinion from the previous round. To describe/ illustrate their agreement, the questionnaire instrument in the form of a five-point Likert scale shown in Table 1.

Table 1 Likert Scale

\begin{tabular}{cl}
\hline Group & Interpretation \\
\hline 5 & Totally Agree \\
4 & Agree \\
3 & Partially Agree \\
2 & Disagree \\
1 & Totally Disagree \\
\hline
\end{tabular}

Source: Likert (1932)

\section{Findings}

The findings show that the indicators agreed upon by experts appointed shown in Table 1.

Table 1: TVETagogy Indicator Model

\begin{tabular}{|c|c|c|c|c|c|}
\hline \multirow[b]{2}{*}{ No } & \multirow[b]{2}{*}{ Indicator/Item } & \multicolumn{4}{|c|}{ Second and Third Round } \\
\hline & & Mean & Median & QR & $\begin{array}{c}\text { Consensus } \\
\text { Level }\end{array}$ \\
\hline 1 & Technology in TVET pedagogy & 4.64 & 5 & 1 & High \\
\hline 2 & Pedagogy in TVET & 4.64 & 5 & 1 & High \\
\hline 3 & & 4.73 & 5 & 1 & High \\
\hline 4 & Knowledge in TVET & 4.45 & 5 & 1 & High \\
\hline 5 & Work-Based Learning & 4.73 & 5 & 1 & High \\
\hline 6 & Project Oriented Problem Based Learning & 4.00 & 4 & 1 & High \\
\hline
\end{tabular}

All of the constructs agreed upon by the experts are shown in figure 1 . The agreed elements are technology for TVET pedagogy, TVET pedagogy, content in TVET, knowledge in TVET combined with work-based learning and project oriented problem based learning. 
INTERNATIONAL JOURNAL OF ACADEMIC RESEARCH IN BUSINESS AND SOCIAL SCIENCES Vol. 10, No. 3, March, 2020, E-ISSN: 2222-6990 @ 2020 HRMARS
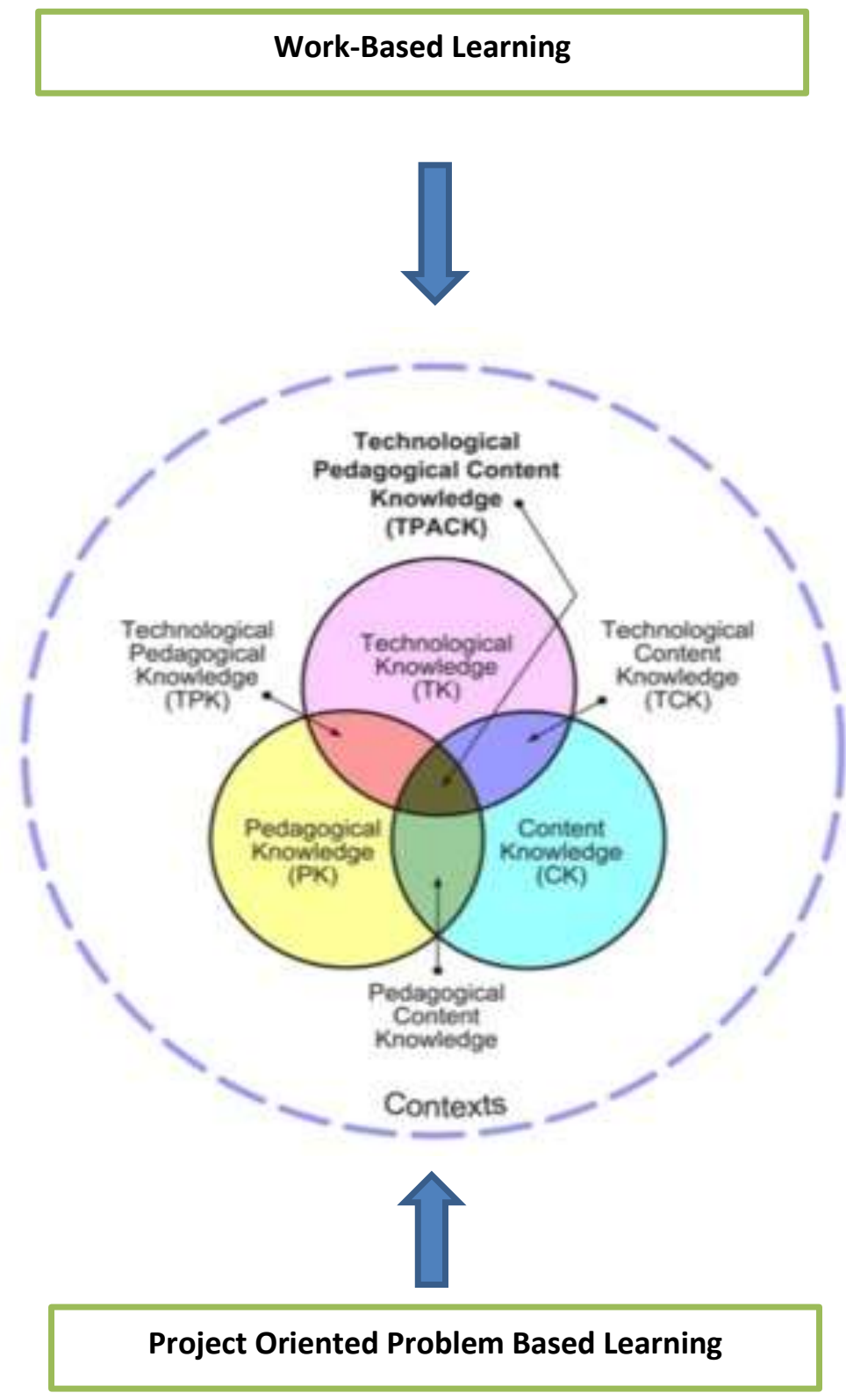

Figure 1: TVETagogy Model (Adaptation: Koehler and Mishra (2009)

\section{Discussion}

Pedagogy in education and technical and vocational training should change according to the needs of the industrial revolution. Elements such as work-based learning are indispensable for the training system is intended to provide employees within the scope of the work required by the industry. The 
INTERNATIONAL JOURNAL OF ACADEMIC RESEARCH IN BUSINESS AND SOCIAL SCIENCES Vol. 10, No. 3, March, 2020, E-ISSN: 2222-6990 C 2020 HRMARS

injection of problem learning elements combined with project oriented problem based learning that requires TVET trainers to be given the skills to solve problems in the learning and facilitating process. These findings are supported by previous studies that found that public skills training institutions and work-based learning programs cannot be separated because they need each other (Mohamad and Norhayati, 2011; Aishah et al., 2007; Shamuni and Ruhizan, 2010).

The combination of all the elements of workability and TPACK should be conducted in training institutions to be used as a PdPc process to meet the more challenging 21st century learning requirements. The TVETagogy model that combines all of these elements can help produce qualified vocational and technical education teachers and trainers to become educators.

\section{Conclusion}

In conclusion, this study shows that TVETagogy module via Project Oriented Problem Based Learning and Work Based Learning can enhance teaching and learning effectiveness for Design and Agriculture Technology. The module usability assessment results show that students gain new learning experiences such as learning topics quickly, facilitating understanding and creating fun learning. This module has the potential to be used by the Ministry of Education Malaysia, Lecturers, Teachers and Students in the field of Design and Agriculture Technology.

\section{Acknowledgements}

This article is based on a research project titled Development of Teaching Model for Training Teacher in Technical and Vocational Education and Training at UPSI (TVETaGogy) Via Project Oriented Problem Based Learning and Work Based Learning. The authors would like to thank the Research Management and Innovation Centre (RMIC), Sultan Idris Education University (UPSI) for the University Research Grant (code: 2018-0175-107-01), which helped authors to complete this research.

\section{References}

Abdel-Wahab, M. (2012). Rethinking apprenticeship training in the British construction industry. Journal of Vocational Education \& Training, 64(2), 145-154. doi:10.1080/13636820.2011.622450.

Cheong, K. C., \& Lee, K. H. (2016). Malaysia's education crisis-can TVET help?. Malaysian Journal of Economic Studies, 53(1), 115.

Choy, S., \& Haukka, S. (2009). Industrial attachments for instructors in TVET delivery. In International handbook of education for the changing world of work (pp. 1367-1382). Springer, Dordrecht.

Chua, J. H., \& Jamil, H. (2012). Factors influencing the Technological Pedagogical Content Knowledge (TPACK) among TVET instructors in Malaysian TVET institution. Procedia-Social and Behavioral Sciences, 69, 1539-1547.

Jusoh, I. (2016). Cara Pengajaran Perlu Berubah Mengikut Kehendak Zaman. Bernama. Akses 23 Ogos 2019.

Alias, N. (2019). Tambah Kemahiran Guru TVET. Harian Metro. 10 Jun 2019

Julie, E., Mills, \& David, F. T. (2003). Engineering Education - Is Problem- Based Or Project-Based Learning The Answer?. Australasian J. of Engng. Educ., online publication 2003-04. 
INTERNATIONAL JOURNAL OF ACADEMIC RESEARCH IN BUSINESS AND SOCIAL SCIENCES

Vol. 10, No. 3, March, 2020, E-ISSN: 2222-6990 @ 2020 HRMARS

Koehler, M., \& Mishra, P. (2009). What is technological pedagogical content knowledge (TPACK)?. Contemporary issues in technology and teacher education, 9(1), 60-70.

Lucas, B. (2014a). Vocational Pedagogy: What it is, why it matters and what we can do about it. Background Note for UNESCO-UNEVOC e-Forum.

Lucas, B. (2014b). Vocational Pedagogy: What it is, why it matters and how to put it into practice.

Majumdar, S. (2011). Teacher education in TVET: Developing a new paradigm. International Journal of Training Research, 9(1-2), 49-59.

Ibrahim, N., \& Abd.Halim, S. (2013). Implementation of Project-Oriented Problem-Based Learning (POPBL) in Introduction to Programming Course.

The $4^{\text {th }}$ International Research Symposium on Problem-Based Learning (IRSPBL) 2013.

Paryono, P. (2015). Approaches to preparing TVET teachers and instructors in ASEAN member countries.TVET@Asia, 5, 1-27.

Ridzwan, R. C., Yasin, R. M., Yunus, F. A. N., Rahim, M. B., \& Ismail, I. M. (2015). Skilling for job: A grounded theory of vocational training at industrial training institutes of malaysia. ProcediaSocial and Behavioral Sciences, 204, 198-205.

UNESCO UNEVOC TVET. (2017). Leadership Programme for Southern and Eastern Africa Capacity Building for Transformational TVET Leaders: vision, knowledge and skills. 